\title{
Elementos pós-Keynesianos e Estruturalistas para a análise da vulnerabilidade externa Latino-Americana no contexto de finanças globalizadas
}

\author{
Saulo Quadros Santiago* \\ Adriana Moreira Amado ${ }^{+}$
}

\begin{abstract}
Resumo
O artigo analisa a vulnerabilidade externa dos países periféricos latino-americanos, no contexto da globalização financeira. Para isso, busca desenvolver uma abordagem que integre os elementos da teoria estruturalista, que considera as especificidades produtivas e tecnológicas desses países, com os da teoria pós-keynesiana, que ressalta as especificidades monetárias e financeiras. Argumenta-se, então, que os países da América Latina são mais vulneráveis a oscilações na preferência pela liquidez internacional do que os países centrais, devido ao baixo desenvolvimento dos seus sistemas nacionais de inovação, à concentração da sua pauta de exportações em bens primários e da sua pauta de importação em bens de capital e insumos processados, à baixa liquidez de suas moedas no cenário externo, à sua inserção marginal nos fluxos internacional de capital e ao baixo desenvolvimento dos seus sistemas financeiros domésticos.
\end{abstract}

Palavras-Chave: Globalização Financeira, Vulnerabilidade Externa, América Latina.

\begin{abstract}
The article analyzes the external vulnerability of Latin-American peripheral countries in financial globalization. For this purpose, it develops an approach that integrates elements of structuralist theory, which considers the productive and technological specificity of these countries, with the post-Keynesian theory, which emphasizes the monetary and financial specificities. It is argued then that Latin-American countries are more vulnerable to swings in international preference for liquidity than the central countries, due to: the low development of their national innovation systems; the concentration of its exports on primary goods and of their import on capital goods and on manufactured inputs; the low liquidity of their currencies; its marginal insertion in international capital flows; and the low development of its domestic financial system.
\end{abstract}

Keywords: Financial Globalization, External Vulnerability, Latin America.

JEL Classifcation: B50; F65; G15; O16

\footnotetext{
* Doutor em economia pela Universidade de Brasília e pesquisador do IPEA

+ Professora do Departamento de Economia da Universidade de Brasília
} 


\section{Introdução}

O termo "globalização financeira" refere-se à capacidade estratégica de atuação em âmbito "global" do investidor financeiro no processo de composição de suas carteiras de ativos e na realização de operações de arbitragem entre diferentes instrumentos financeiros, compartimentos e países, onde eles são negociados (Chesnais, 2005). Mais precisamente, "globalização financeira" diz respeito à integração entre os mercados financeiros onshore (sujeitos à jurisdição nacional) e offshore (não sujeitos à jurisdição nacional) e entre os mercados onshore, possibilitada por meio de decisão política dos diversos Estados nacionais. Segundo Chesnais (2005), apesar do processo de mundialização ${ }^{1}$ financeira ter sido iniciado em 1958, com a criação do mercado de "eurodólares" ${ }^{2}$, e ter se favorecido posteriormente pelo colapso do sistema de Bretton Woods e implementação de um sistema de câmbio flexível, foi em 1979-81, com as medidas de liberalização e desregulamentação dos mercados de dívidas públicas, concomitante à alta do dólar e das taxas de juros norte-americanas, que o sistema financeiro globalizado contemporâneo ganhou impulso. Nas palavras do autor:

“A mundialização financeira foi preparada pelo mercado de eurodólares, depois pela passagem a um regime de taxas de câmbio flexíveis após o colapso do sistema de Bretton Woods. O mercado de câmbio foi, assim, o primeiro a entrar na mundialização financeira contemporânea. Ele permanece um dos mercados onde os investidores internacionais continuam a manter parte de seus ativos. Mas foram as medidas de liberalização e de desregulamentação de 1979-81 que deram nascimento ao sistema de finança mundializado tal como o conhecemos" (Chesnais, 2005, p. 44)

Desde o final da década de 1970, tem sido observado um movimento de abertura das contas de capital e financeira dos balanços de pagamentos de diversas economias desenvolvidas, facilitando tanto o acesso aos ativos financeiros domésticos e à moeda nacional aos não residentes, quanto o acesso aos ativos e moedas estrangeiras aos residentes domésticos. Desta maneira, há uma tendência à unificação dos diversos mercados financeiros em âmbito externo e interno ${ }^{3}$ (Chesnais,2005; Amado, 2004; Plihon, 1995).

A participação das economias periféricas da América Latina ${ }^{4}$ nesse processo, a partir da integração aos mercados financeiros globais, ocorreu principalmente a partir do início da década de 1990. Porém, conforme já destacado pela literatura econômica sobre a região, como Cepal (2001), Ocampo (2001) e Ffrench-Davis e Ocampo (2001), ele culminou com a ocorrência de crises de balanço de pagamentos ainda nessa década e no início da seguinte.

Entre 2003 e 2007, observa-se uma menor volatilidade no mercado financeiro global, coincidindo com uma melhoria e certa estabilidade do desempenho macroeconômico dos países latino-americanos, interrompidas pela crise originada no mercado hipotecário norteamericano em 2007, no segmento de hipotecas de alto risco (subprime), que culminou com a falência do banco de investimentos Lehman Brothers, em setembro de 2008, e cujos impactos recessivos sobre as economias periféricas foram amenizados pela política monetária expansionista dos Estados Unidos, pela realização de políticas anticíclicas domésticas e pela

\footnotetext{
${ }^{1}$ O termo "mundialização" é utilizado como sinônimo de "globalização" por Chesnais (2005).

${ }^{2}$ Mercado financeiro offshore na City de Londres, com ativos denominados em dólar.

3 “A mundialização financeira remete tanto à 'descompartimentalização' interna entre diferentes funções financeiras e diferentes tipos de mercado (de câmbio, de crédito, de ações e obrigações) quanto à interpenetração externa dos mercados monetários e financeiros nacionais e sua integração nos mercados mundializados" (Chesnais, 2005, p. 46).

${ }^{4}$ No restante do trabalho, será usado o termo "economias periféricas" para caracterizar principalmente os países latino-americanos. Apesar da maioria das economias asiáticas ser periférica, elas não serão consideradas na análise, por ter características diferentes da América Latina, no que diz respeito aos sistemas financeiros e à competitividade externa.
} 
manutenção do preço internacional de commodities em patamar elevado, influenciada pela demanda chinesa. Porém, a partir de 2013, verifica-se uma contração e um aumento da instabilidade nas economias periféricas, associados à perda de confiança dos investidores internacionais, diante da possibilidade de normalização da política monetária norte-americana e da redução dos preços das commodities (Akyüz, 2015; IMF, 2015a; IMF, 2015b).

A ocorrência de crises de balanço de pagamentos na América Latina na segunda metade da década de 1990 e início da de 2000, a melhoria do seu desempenho macroeconômico entre 2003 e 2007 e a contração e instabilidade observadas após 2008 podem ser relacionadas, em contexto de abertura financeira, a variáveis externas que determinam ou permeiam os ciclos de expansão e contração da liquidez internacional, entre elas, particularmente, o estado de expectativas internacionais. Ademais, diante da observação empírica feita por Resende e Amado (2007) de que os ciclos econômicos da América Latina tenderam a refletir as variações na liquidez internacional, entre 1960 e 2002, é possível argumentar que a trajetória macroeconômica desses países tem sido afetada em graus variados pelo estado das expectativas prevalecente no cenário internacional. Esta influência passa a ser maior conforme o grau de abertura destas economias aos fluxos financeiros internacionais, ou seja, proporcionalmente ao aumento da sua participação no processo de globalização financeira, que, ao incentivar as atividades especulativas, tende a aumentar 0 volume de compras e vendas de ativos financeiros, em âmbito mundial e nacional, e elevar a volatilidade macroeconômica dos diversos países (Plihon, 1995).

Para uma melhor análise da vulnerabilidade externa da América Latina ao estado de ânimo dos investidores internacionais, é preciso retomar os principais conceitos da teoria póskeynesiana e associá-los às especificidades das estruturas produtivas e tecnológicas das economias periféricas, discutidas no âmbito dos trabalhos estruturalistas, e às características das suas moedas nacionais, frente às demais, e dos seus sistemas financeiros domésticos, enfatizadas predominantemente pela teoria pós-keynesiana. Tendo em vista que esse tipo de análise já foi conduzido em outros trabalhos, como Andrade e Prates (2012), De Conti, Prates e Plihon (2014) e Kaltenbrunner (2015), mas sem levar em consideração elementos destacados pela teoria neoestruturalista, este trabalho buscará integrá-los na caracterização dos países periféricos da América Latina, de forma a avançar na discussão e a contribuir para um entendimento mais amplo da volatilidade macroeconômica que tem sido observada nessas economias, no contexto de aumento da sua integração aos mercados financeiros globais.

Além desta introdução, o trabalho será desenvolvido em mais cinco seções. A seção 2 procura fornecer os elementos principais da teoria da preferência pela liquidez póskeynesiana, de forma a ressaltar a predominância do comportamento especulativo, em âmbito global, e os seus impactos sobre os juros, a taxa de câmbio e os preços dos ativos. Na seção 3, adota-se a hipótese de fragilidade financeira de Minsky (1986) para economias abertas, enfatizando o processo de financiamento e consolidação do investimento. Na seção 4, analisase a concepção do sistema centro-periferia feita pelos estruturalistas e neoestruturalistas, associando-a aos elementos da teoria pós-keynesiana. A seção 5 procura examinar a inserção das economias periféricas no cenário internacional, a partir de um referencial teórico keynesiano-estruturalista. A seção 6 analisa a vulnerabilidade externa da América Latina, utilizando os elementos pós-keynesianos, estruturalistas e neoestruturalistas destacados ao longo do trabalho.

\section{A Teoria da Preferência pela Liquidez no Contexto da Globalização Financeira}

A teoria da preferência pela liquidez pós-keynesiana, baseada nos trabalhos desenvolvidos por Keynes após 1936, destaca-se das demais abordagens econômicas por trabalhar com a perspectiva de economia monetária de produção, caracterizada por tempo histórico, incerteza 
e moeda ${ }^{5}$, elementos que não podem ser compreendidos de forma independente um dos outros (Dow, 1985; Carvalho, 1992) ${ }^{6}$. Esses elementos, por sua vez, se refletem no processo de escolha de ativos. Diante da incerteza que permeia a economia capitalista, a moeda passa a ser vista como um ativo que possui como atrativo uma liquidez superior aos demais, proporcionando ao seu detentor maior segurança e flexibilidade para tomar decisões, sem que sua posse acarrete em perdas significativas de valor ao longo do tempo (Keynes, 1936; Dequech, 2000).

Devido aos seus atributos de elasticidades de produção e substituição negligenciáveis (Keynes, 1936), um aumento da participação da moeda em detrimento dos demais ativos no portfólio dos agentes tem como consequência uma redução no emprego, no investimento e no nível de atividade, o que resulta na sua não neutralidade sem a existência de mecanismos limitadores intrínsecos para tal, no curto e no longo prazo. Além disso, diante da incerteza, os animal spirits e as convenções ganham importância na determinação do portfólio dos agentes, o que resulta no aumento do grau de instabilidade da demanda por moedas e ativos e, portanto, na volatilidade do investimento (Keynes, 1937).

Conforme ressaltado por Amado (2004), a teoria da preferência pela liquidez continua válida mesmo no contexto de globalização financeira, em que os avanços nas tecnologias da informação e comunicação, concomitantes ao movimento de abertura e liberalização das economias domésticas, traduziram-se em aumento da liquidez dos mercados de ativos e moedas. Ainda nesse cenário, a moeda nacional continua possuindo o prêmio máximo de liquidez, em âmbito exclusivamente doméstico, uma vez que mantém os seus atributos de elasticidades de produção e substituição próximas a zero, o que contribui para que seu valor apresente maior estabilidade em comparação com o dos demais bens e, consequentemente, para que ela permaneça como a unidade de conta para a denominação da maioria dos contratos internamente, em especial dos contratos salariais, conferindo flexibilidade para 0 seu detentor ${ }^{7}$. Sendo o trabalho o insumo mais geral e comum, no âmbito da produção capitalista, seus contratos ganham importância para a tomada de decisão, favorecendo o elevado prêmio por liquidez da moeda (Amado, 2004; Keynes, 1936). Nas palavras de Keynes (1936):

“(...) o fato de serem os contratos fixos e de serem os salários geralmente bastante estáveis, em termos de moeda, contribui sem dúvida em larga medida para que a moeda tenha um prêmio de liquidez tão elevado." (Keynes, 1936, p. 185)

Sobre essa questão, Amado (2004) enfatiza:

"A liquidez da moeda deve-se em grande parte ao fato de o trabalho ser o insumo mais comum, geral, das economias monetárias de produção, e de sua remuneração ser feita em termos monetários, e essa remuneração ter por base contratos que são, também, monetários, o que, em certo sentido, fornece uma âncora à moeda." (Amado, 2004, p. 504)

\footnotetext{
${ }^{5}$ Uma lista mais completa de fundamentos que caracterizam uma economia monetária de produção pode ser obtida em Carvalho (1992).

${ }^{6}$ Carvalho (1992) observa que os fundamentos da teoria pós-keynesiana não podem ser categorizados como axiomas, os quais são amplamente utilizados pela teoria neoclássica, sendo entendidos como hipóteses que não podem ser explicadas por meio de outras. Em outras palavras, axiomas são ideias ou concepções irredutíveis. Eles são considerados como átomos, independentes um do outro, que podem ser combinados e daí resultar em uma teoria. Como moeda, tempo histórico e incerteza constituem-se elementos que não podem ser compreendidos de forma independente um do outro, é equivocado considerá-los axiomas.

${ }^{7}$ Por ser unidade de conta dos contratos, a moeda é o ativo utilizado para a liquidação dos passivos deles provenientes.
} 
Por continuar sendo o ativo mais líquido da economia, em âmbito doméstico, a moeda nacional ainda é demandada para atender aos motivos transação, precaução e especulação. Porém, conforme observado por Dow (1999), desvalorizações cambiais e dinâmicas inflacionárias podem diminuir a sua demanda, já que diminuem sua capacidade de desempenhar a função de reserva de valor. Assim, em cenários de deterioração da taxa de câmbio ou de inflação, os agentes residentes podem buscar algum outro ativo substituto para a moeda nacional, para uso em âmbito doméstico, que possua maior liquidez, como é o caso do dólar, que apresenta maior capacidade de desempenhar a função de reserva de valor, sendo também utilizado para a liquidação da maior parte dos contratos internacionais (Kaltenbrunner, 2015; Carneiro, 2008).

Ao possibilitar a atuação, em escala global, do investidor financeiro na composição do seu portfólio, tornar cada vez mais fácil a transação de ativos financeiros e moedas entre países e elevar os riscos decorrentes da variação das taxas de câmbio e dos preços dos ativos, estimulando o surgimento de inovações financeiras, como derivativos e títulos securitizados, a globalização financeira tem favorecido a atividade especulativa no contexto mundial (Guttmann, 2015; Torres Filho, 2014; Amado, 2004; Plihon, 1995). Nesse sentido, há uma elevação no volume de negociações envolvendo moedas, títulos públicos e privados, de renda fixa e variável, entre países, visando a obtenção de ganhos de capital de curto prazo. Essas operações são guiadas por expectativas de valorização dos ativos e das moedas em curto período de tempo. Como ressaltado por Keynes (1936), o especulador busca antecipar a psicologia do mercado, visando obter ganhos financeiros. Diante da incerteza que permeia a economia, essas expectativas de ganhos de capital são influenciadas pelas convenções ${ }^{8}$. A volatilidade destas eleva o grau de instabilidade das negociações entre moedas e ativos financeiros, o que aumenta ainda mais a incerteza em âmbito doméstico e internacional.

A ampliação do leque de ativos financeiros passíveis de serem incorporados nos portfólios dos agentes e a elevação da volatilidade das expectativas de ganhos de capital tendem a reforçar a demanda pela moeda pelo motivo especulação. Mais especificamente, o aumento da incerteza resultante do crescimento do grau de instabilidade dos preços dos ativos e das taxas de câmbio aprofunda a preferência pela liquidez dos agentes residentes, em âmbito doméstico (Amado, 2004). Considerando que a taxa de juros consiste no prêmio demandado pelos agentes para que eles abram mão da liquidez máxima representada pela moeda e que a moeda nacional, enquanto for utilizada como unidade de conta e meio de liquidação dos contratos domésticos, continua sendo o referencial máximo de liquidez internamente ${ }^{9}$, quanto maior for a preferência pela liquidez, maior será a taxa de juros. Em outras palavras, a volatilidade macroeconômica aumenta a incerteza a que estão sujeitos os agentes, tendo impactos sobre a taxa de juros.

É importante destacar que, diante dos atributos de baixas elasticidades de produção e de substituição da moeda, a preferência pela liquidez, juntamente com a eficiência marginal do capital, permanece sendo elemento fundamental para a explicação do investimento e,

\footnotetext{
${ }^{8}$ Segundo Andrade e Prates (2012), as convenções são "uma forma de conhecimento social tácito, geralmente com base na experiência passada e nas interações entre os agentes no espaço e no tempo. As convenções são a incorporação de um tipo de conhecimento que foi gerado a partir da ação intersubjetiva no tempo histórico" (Andrade e Prates, 2012, p. 239).

9 "Uma vez que os salários e a maioria dos contratos são determinados em moeda nacional, esta é a que atrai para si o atributo de liquidez máxima. O que ocorre com o desenvolvimento financeiro associado à globalização e à consequente abertura das contas de capitais é uma aproximação dos vários ativos, com seus ganhos de liquidez, do referencial de liquidez que é representado pela moeda nacional e a consequente ampliação da esfera da especulação no sistema como um todo. Contudo, em momento algum a moeda perde seu papel de referência de liquidez" (Amado, 2004, p. 504)
} 
portanto, do nível de emprego e de renda. Assim, a elevação da preferência pela liquidez, diante do aumento da percepção de incerteza, tende a ter impactos negativos sobre o desempenho macroeconômico doméstico. Em outras palavras, o aumento da instabilidade gerado pelo aprofundamento da globalização financeira influencia o desempenho real das economias nacionais.

No entanto, ressalta-se que o fato de uma moeda ser o ativo mais líquido no seu país emissor não implica necessariamente que ela tenha o mesmo atributo de liquidez no cenário internacional. A liquidez internacional de um ativo depende da sua capacidade de ser convertida em um meio de pagamento internacionalmente aceito, no menor intervalo de tempo possível, sem incorrer em perda de valor para o seu proprietário (Chick, 1983; Carvalho, 1992). Nesse sentido, a moeda que conseguir desempenhar de forma mais ampla as suas funções de meio de pagamento, unidade de conta e reserva de valor, no contexto internacional, será por definição o ativo com maior liquidez internacional, uma vez que a sua liquidez depende da sua capacidade de se transformar em si mesmo. Observa-se, assim, a existência de uma hierarquia internacional entre as diversas moedas segundo o seu grau de liquidez e conversibilidade de fato ${ }^{10}$ (De Conti, Prates e Plihon, 2014, 2015; Kaltenbrunner, 2015; Andrade e Prates, 2012; Carneiro, 2008). O posicionamento de uma determinada moeda na hierarquia do sistema monetário internacional depende de variáveis geopolítica e geoeconômicas, havendo destaque para:

“i) a dimensão da economia emissora da moeda em questão e sua integração (comercial e financeira) com o restante do mundo; ii) o poder político de cada país no cenário internacional (nas relações bilaterais e, igualmente, junto às instituições multilaterais); e iii) o 'voluntarismo político', a saber ações deliberadas de um governo nacional com o intuito de intensificar o uso internacional de sua moeda." (De Conti et al. , 2014, pp. 345-346)

Tendo em vista que o conjunto dessas variáveis pode sofrer alterações apenas no longo prazo, sendo resultado de transformações no contexto geopolítico e geoeconômico mundiais, existe uma inércia no que diz respeito à posição das moedas na hierarquia do sistema monetário internacional. Como esta não pode ser alterada no curto prazo por meio da ação isolada de um só país, o contexto internacional vigente age frequentemente como um fator de restrição às políticas nacionais, exercendo influência crucial sobre a dinâmica das taxa de juros e das taxa de câmbio, de forma diferenciada entre os diversos países, segundo o posicionamento da sua moeda na hierarquia internacional e o seu grau de abertura financeira (De Conti, Prates e Plihon, 2014, 2015; Kaltenbrunner, 2015; Andrade e Prates, 2012).

Por sua vez, a liquidez dos ativos financeiros é influenciada pela moeda que constitui sua unidade de conta. Nesse sentido, ativos denominados em dólar possuem seus rendimentos também em dólar e podem ser mais facilmente vendidos em troca desta moeda. Assim, eles normalmente possuem elevada liquidez. Já os ativos denominados em moedas com posicionamento inferior na hierarquia internacional possuem menor liquidez, uma vez que eles precisam ser inicialmente convertidos na moeda do seu país emissor e, posteriormente, em uma divisa com liquidez mais elevada. Dessa forma, há um número maior de etapas ao longo desse processo, além de haver um risco maior de perda de valor em termos da divisa-chave.

\footnotetext{
${ }^{10}$ A conversibilidade de fato diz respeito à capacidade de a moeda desempenhar, na prática, as suas funções clássicas, no cenário internacional. Ela se diferencia da conversibilidade de jure, que se refere à existência de um arcabouço legal que elimine as restrições para que a moeda nacional seja utilizada nas transações envolvendo moedas e ativos estrangeiros, ou seja, que suprima os controle sobre os fluxos internacionais de capital. Para mais detalhes sobre essa discussão, ver Belluzzo e Carneiro (2004).
} 
Em contexto de expansão da liquidez internacional e, consequentemente, redução da preferência pela liquidez dos investidores que operam em âmbito global, costuma haver aumento da demanda por moedas de baixa liquidez e de ativos financeiros nelas denominados, devido às expectativas de valorização no curto prazo. À medida que esse cenário de otimismo se prolonga, há tendência de realização dessas expectativas, havendo, de fato, uma valorização cambial, que reforça a demanda por essas moedas (Andrade e Prates, 2012). É importante enfatizar que a ampliação da liquidez internacional implica também em menores taxas de juros internacional e doméstica e, portanto, em menor custo para a tomada de empréstimo, o que impulsiona essa dinâmica.

Como estas expectativas são voláteis, baseadas em convenções, essa fase é geralmente alternada por outra de contração da liquidez e aumento da desconfiança dos investidores internacionais. Uma vez que as moedas que ocupam as posições inferiores na hierarquia do sistema monetário internacional possuem menor capacidade de desempenhar suas funções clássicas, elas deixam de ser demandadas, havendo também redução da demanda por ativos financeiros nela denominados (De Conti, Prates e Plihon, 2014; Andrade e Prates, 2012). Ocorre, assim, uma desvalorização cambial, concomitante a um aumento das taxas de juros internacional e doméstica. Dessa forma, observa-se que a volatilidade da preferência pela liquidez e das expectativas no cenário internacional exercem impactos significativos tanto sobre a taxa de juros, quanto sobre a taxa de câmbio dos diversos países, segundo a posição de sua moeda na hierarquia do sistema monetário internacional.

Em relação à taxa de câmbio, é importante ressaltar que, no contexto da globalização financeira, ela passa a ser determinada em grande parte pela conta financeira do balanço de pagamentos, uma vez que os fluxos financeiros brutos entre países passaram a ter um volume significativamente superior aos fluxos comerciais (Harvey, 1999; Plihon, 1995). Como os fluxos financeiros para os países com moedas de baixa conversibilidade são bastante influenciados pelas expectativas voláteis de valorização de curto prazo de sua moeda e dos ativos nela denominados, suas taxas de câmbio adquirem um elevado grau de instabilidade.

\section{Financiamento Externo e Fragilidade Financeira em Economias Abertas}

Além de ter conferido maior liberdade para as compras e vendas de ativos e moedas entre residentes e não residentes de um determinado país, a globalização financeira também tem proporcionado um aumento significativo do fluxo de crédito e depósito através das diversas fronteiras nacionais. É importante destacar também a atuação crescente de investimentos estrangeiros em títulos de renda fixa e ações nos mercados domésticos. Nesse sentido, possibilita-se que os bancos e investidores institucionais ${ }^{11}$ passem a atuar em escala cada vez mais global.

Diante do aumento dos fluxos financeiros entre residentes de diferentes países e do crescimento de despesas operacionais e financeiras denominadas em moeda estrangeira, recorre-se ao arcabouço teórico minskyano de fragilidade financeira para economias abertas, de forma a obter uma melhor interpretação da instabilidade apresentada pelo capitalismo, principalmente a partir do final da década de $1970^{12}$. O conceito de fragilidade financeira está relacionado à forma como são financiadas as posições em ativos e ao caráter incerto das

\footnotetext{
11 Termo utilizado para tratar dos agentes, como fundos de pensão, fundos de investimento e sociedades de seguros, cujas principais operações consistem na compra e venda de títulos (de renda fixa ou variável) que rendem juros ou dividendos (Chesnais, 2005).

${ }^{12}$ A utilização do arcabouço teórico minskyano para a explicação de fragilidade financeira em economias abertas também pode ser vista em outros trabalhos pós-keynesianos, como Kregel (1998), Dymski (1998), De Paula e Alves Jr (1999), Arestis e Glickman (2002) e Resende e Amado (2007).
} 
expectativas de receitas, fundamentais para honrar os compromissos financeiros firmados. Considerando que as receitas futuras possuem caráter mais remoto, ao passo que os compromissos financeiros contraídos no passado e no presente apresentam maior rigidez ou grau de certeza, Minsky (1986; 1992), no desenvolvimento de sua teoria sobre fragilidade financeira, focada originalmente em economias fechadas, classificou as unidades econômicas, em termos das suas estruturas financeiras em três tipos, a partir da relação entre as expectativas de renda futura e os pagamentos contratuais: (i) unidades hedge; (ii) unidades especulativas; e (iii) unidades Ponzi.

As unidades hedge consistem naquelas cujas expectativas de rendimentos monetários são superiores às obrigações financeiras, em qualquer período do tempo. Nesse sentido, sua margem de segurança é suficiente para acomodar qualquer alteração que pode ocorrer no mercado financeiro, como, por exemplo, elevação na preferência pela liquidez, que se reflete em aumento das taxas de juros. No entanto, ela é vulnerável a oscilações nos mercados de bens e serviços, como reduções na demanda, que podem comprometer suas rendas futuras (Minsky, 1986).

As unidades especulativas, segundo Minsky (1986), consistem naquelas cujas expectativas de fluxos de caixa são suficientes para o pagamento dos juros resultantes das dívidas contraídas, mas insuficientes para a amortização de algumas parcelas do principal. Em outras palavras, as unidades especulativas possuem compromissos contratuais em montante superior às suas quase-rendas até determinado período de tempo, mas, a partir dele, esperam gerar rendas suficientes para honrar o passivo contraído. Para obter recursos monetários necessários ao pagamento dos seus compromissos contratuais, nos períodos iniciais, ela busca refinanciar a sua dívida, especulando, assim, sobre as condições futuras do mercado financeiro, ou então, vender os seus ativos. Uma eventual oscilação na preferência pela liquidez pode dificultar o refinanciamento, por aumentar as taxas de juros. Um processo de desvalorização de ativos também criar obstáculos para a obtenção de recursos para honrar os seus compromissos. Em caso de aumento das taxas de juros e/ou de desvalorização de ativos, essas unidades não conseguem pagar os seus passivos contratuais, tornando-se insolvente.

Finalmente, as unidades Ponzi são aquelas cujas expectativas de fluxos de caixa futuros são insuficientes para pagar tanto o principal da dívida contraída, quanto os seus juros, por isso tendem a contrair novos empréstimos para poder honrar seus compromissos contratuais. Ao longo de todo o período de tempo em consideração, elas não conseguem obter quase-rendas em montante necessário para pagar os passivos contraídos, a menos que haja algum choque muito favorável na economia (Minsky, 1986). Assim, suas dívidas crescem ao longo do tempo, evidenciando, para os credores, sua condição de insolvência. A vulnerabilidade das unidades Ponzi a alterações na preferência pela liquidez do mercado financeiro ou a um processo de desvalorização de ativos é ainda superior à vulnerabilidade apresentada pelas unidades especulativas.

Quanto maiores forem o grau de incerteza relacionado aos fluxos futuros de caixa e o valor dos passivos contraídos, mais frágil será a estrutura financeira, sendo mais predominantes as unidades especulativas e Ponzi em relação às unidades hedge. Essa fragilidade pode se manifestar, por exemplo, na demanda por refinanciamentos ou empréstimos adicionais junto ao sistema financeiro para fazer face aos compromissos em vencimento.

Em economias abertas, na medida em que há possibilidade de que as receitas sejam denominadas em moedas distintas daquelas em que as despesas e os compromissos contratuais estão denominados, o preço relativo das moedas passa a ser um elemento adicional de incerteza (Kaltenbrunner, 2015; Arestis e Glickman, 2002; De Paula e Alves Jr, 1999). Diante de uma desvalorização cambial, as receitas podem não se mostrar suficientes 
para honrar os passivos em moeda estrangeira, conforme foi inicialmente esperado. Nesse sentido, torna-se necessário recorrer ao mercado financeiro externo para viabilizar o pagamento dos compromissos em aberto.

Diante da ocorrência de descasamento de unidades de conta entre receitas e pagamentos contratuais, a oferta de crédito por parte das instituições financeiras internacionais depende do estado de expectativa quanto a capacidade do tomador de empréstimo gerar divisas estrangeiras em montante suficiente para cobrir tanto suas despesas operacionais, caso ela esteja denominada em moeda estrangeira, quanto a amortização e os juros do passivo externo. Caso o prazo do passivo do devedor seja inferior ao prazo de maturação do seu ativo, a geração de fluxo de caixa em moeda estrangeira em montante suficiente para o pagamento dos compromissos financeiros será influenciada por variações de curto prazo na taxa de câmbio, além das flutuações da taxa de juros internacional. Essas duas variáveis, em conjunto, afetam as condições de refinanciamento do passivo externo.

Nos casos de investimentos estrangeiros de portfólio no mercado doméstico, a perspectiva de desvalorização cambial e de queda nos preços dos ativos afetam negativamente a compra de títulos de renda fixa e ações denominados em moeda nacional, uma vez que se refletem em potenciais perdas para o agente que deseja posteriormente converter para moeda estrangeira os recursos aplicados e os respectivos rendimentos (Cintra, 2015; Biancareli, 2015). Assim, as expectativas de variações da taxa de câmbio e dos preços dos ativos influenciam a disponibilidade de investimentos de portfólio estrangeiro no mercado doméstico.

Uma vez que está relacionada a condicionantes macroeconômicos, a análise e a avaliação da capacidade do devedor gerar divisas estrangeiras e a perspectiva do investidor estrangeiro no mercado de portfólio doméstico converter futuramente seus recursos para moeda estrangeira, sem incorrer em perdas, transcendem o nível microeconômico da firma e passam a englobar o país como um todo, levando em consideração o seu balanço de pagamentos. Dessa forma, os próprios países podem ser classificados estilizadamente como unidades hedges, especulativas ou Ponzi, de acordo com a estrutura do seu balanço de pagamentos (De Paula e Alves Jr, 1999).

Os países classificados como hedges seriam aqueles capazes de gerar divisas em montante suficiente para honrar os compromissos financeiros e correntes com o exterior, por meio de receitas correntes ou da venda de ativos no mercado externo. Dessa forma, economias com elevada competitividade, que emitem moeda com elevada liquidez externa, tendem a ser classificados como hedge. Particularmente, aquelas cujas moedas estão situadas próximas ao topo da hierarquia monetária internacional, tendem a ser capazes de emitir um elevado percentual, senão a totalidade, do seu passivo externo em moeda local, conseguindo gerar fluxos de caixa suficientes para o pagamento dos compromissos firmados com 0 exterior ${ }^{13}$.

Os países especulativos seriam aqueles sem a mesma capacidade de geração de divisas estrangeiras, que possuem baixa competitividade e cujas moedas estão situadas em posições inferiores na hierarquia monetária internacional e, por isso, necessitam recorrer frequentemente a refinanciamentos junto aos mercados externos (ou ao estoque acumulado de reservas) para viabilizar a realização de gastos correntes e o pagamento dos compromissos financeiros, ambos em moeda estrangeira. Por fim, as unidades Ponzi seriam o caso extremo das unidades especulativas, apresentando passivo externo crescente ao longo do tempo,

\footnotetext{
${ }^{13}$ É importante destacar que os Estados Unidos, por ser o país emissor da divisa-chave, situada no topo da hierarquia internacional, conseguem emitir dívida em sua própria moeda no mercado externo (Kaltenbrunner, 2015; Carneiro, 2008). Por isso, é classificado como unidade hedge.
} 
devido a insuficiência de receitas em moeda estrangeira para fazer face aos pagamentos tanto do principal da dívida externa, quanto dos seus juros.

É importante ressaltar que, assim como destacado por Minsky (1986), a vulnerabilidade externa de um país e sua consequente classificação em unidade hedge, especulativa ou Ponzi estão relacionadas ao valor dos compromissos contratuais e à perspectiva de obtenção de fluxo de caixa em montante suficiente para liquidá-los. A principal diferença entre as análises para economias fechadas e para economias abertas diz respeito à possibilidade de financiar posições em ativos a partir de obrigações denominadas em moeda estrangeira ${ }^{14}$, o que se torna mais frequente para as economias cujas moedas possuem baixa liquidez, estando em posição inferior na hierarquia internacional (Kaltenbrunner, 2015). Por sua vez, a capacidade de pagamento desses compromissos depende da capacidade de obtenção de divisas por meio de operações correntes e financeiras com o resto do mundo e, em último caso, da queima de parcela do estoque acumulado de reservas cambiais.

A capacidade de geração de divisas, ao longo do tempo, de um país cuja moeda e ativos financeiros possuem baixa liquidez internacional ${ }^{15}$ está normalmente associada ao padrão histórico da conta de transações correntes do balanço de pagamentos e aos fatores estruturais que condicionam a sua inserção no cenário internacional (Resende e Amado, 2007). Caso o resultado em transações correntes seja historicamente negativo, mesmo em contexto de expansão da liquidez internacional, isso pode significar uma eventual dificuldade de obtenção de receitas correntes externas em montante suficiente para fazer face tanto às despesas relacionadas ao serviço da dívida, como juros e dividendos externos, quanto aos gastos operacionais com importação de bens e serviços.

Nesse caso, o país necessita continuamente refinanciar o seu passivo para fazer face aos gastos correntes e compromissos financeiros externos, estando vulnerável a variações na taxa de câmbio e na taxa de juros internacional, o que pode exercer impacto negativo no saldo em transações correntes, por meio das rubricas de pagamentos de juros e dividendos. 0 aumento progressivo dos pagamentos de juros internacionais, por sua vez, pode resultar em crescimento também do principal do passivo acumulado, aumentando as despesas futuras com amortização da dívida e, portanto, a perspectiva de deficit futuro também na conta financeira do balanço de pagamentos diante de uma eventual contração da liquidez internacional e redução da oferta de financiamento estrangeiro. Assim, há uma tendência a geração de desequilíbrios no balanço de pagamentos, nos países com deficits crônicos em conta-corrente e com moeda em posição inferior na hierarquia internacional.

De forma análoga ao que ocorre em economias fechadas, demanda-se moeda pelo motivo finanças para a viabilização da tomada de decisão de investir. Entretanto, no caso do bem de capital ser produzido por outro país, a moeda que atende a esse motivo é a estrangeira, não a nacional, a não ser que a moeda emitida pela economia importadora em questão esteja em posição superior na hierarquia internacional.

Se o país investidor não possui divisas estrangeiras em montante suficiente, ele recorre a financiamentos em moeda estrangeira. Não é necessária, assim, poupança prévia para o aumento do investimento, mas sim uma disposição dos bancos internacionais e dos demais agentes não residentes em se tornarem menos líquidos e, assim, ofertarem divisas para a economia doméstica.

\footnotetext{
${ }^{14}$ No caso de investimentos estrangeiros no mercado de portfólio local, em uma economia com livre conversibilidade da conta financeira, essa obrigação continua existindo, uma vez que, a qualquer momento, o investidor pode desejar converter para moeda estrangeira os ativos adquiridos.

${ }^{15}$ Países com moeda e ativos financeiros líquidos, no cenário internacional, conseguem vendê-los facilmente em troca das divisas necessárias, sem incorrer em perdas significativas de valor.
} 
Por sua vez, os investimentos realizados permitem que a economia em questão produza bens, os quais podem ser destinados ao mercado interno ou ao externo. Nesse contexto, as exportações constituem importantes fontes de receita em moeda estrangeira, podendo propiciar o funding necessário para consolidar o investimento (Resende, 2007). Entretanto, não há nada que garanta que o país conseguirá gerar receitas de exportação em montante suficiente para isso. Para obter as receitas necessárias em moeda estrangeira, é preciso que ele seja competitivo no cenário internacional.

Assumindo-se que o país não possua reservas cambiais suficientes, caso ele não consiga obter recursos em moeda estrangeira, por meio da exportação, no valor devido para consolidar o investimento, será preciso recorrer a um refinanciamento do passivo, seja a partir de novas dívidas, seja a partir de venda de ativos financeiros a agentes não residentes, nos mercados domésticos ou externos. Nesse caso, o deficit comercial em conjunto com os pagamentos de juros e dividendos ao exterior se refletem em um deficit na conta de transações correntes do balanço de pagamentos. Assim, os países com baixo grau de diversificação da estrutura produtiva, que não conseguem produzir os bens de capital necessários para o seu desenvolvimento, que não possuem competitividade suficiente no comércio internacional e cuja moeda ocupa posição inferior na hierarquia internacional ${ }^{16}$, podem ser classificados como unidades especulativas ou Ponzi. Eles precisam de constantes ou até crescentes financiamentos junto ao exterior para possibilitar simultaneamente o seu desenvolvimento e o pagamento dos compromissos externos.

É importante observar que as condições de oferta de financiamento externo são balizadas pela expectativa de geração de divisas estrangeiras por parte do país tomador de empréstimo, em montante suficiente para fazer face às despesas abrangidas tanto na conta financeira quanto nas transações correntes do balanço de pagamentos. Essa expectativa, por sua vez, depende do histórico de pagamento dos compromissos externos, seja ele viabilizado por esforços produtivos que visem a geração de fluxos de renda em moeda estrangeira, seja ele resultante de refinanciamento externo do passivo ou da utilização de reservas cambiais. Ademais, ao observar que outras instituições estão expandindo financiamentos para uma quantidade maior de países, o credor internacional também aumenta a sua oferta, como forma de manter sua fatia de mercado e porque, em vista da incerteza, crê que as outras instituições podem possuir um conjunto maior de informações confiáveis. O mesmo tipo de raciocínio se aplica para a contração de financiamento, porém em sentido inverso. Por fim, outro importante balizador refere-se à avaliação de risco-país, ou seja, riscos de crédito soberano, efetuadas por bancos de grande porte e agências especializadas e expressadas em ratings e em indicadores como o Emerging Market Bond Index Plus (EMBI+) e o Credit Default Swap (CDS).

Assim, os agentes internacionais recorrem a convenções na formação de expectativa a respeito da solvência das economias devedoras. Em primeiro lugar, tendem a projetar para o futuro a situação presente ou o passado recente, expresso no histórico de pagamento dos compromissos. Em segundo lugar, recorrem a avaliações e aos comportamentos verificados por outras instituições ou pela média do mercado para tomarem as suas decisões. Quanto maior for a percepção de incerteza e, portanto, mais remota a base de informações a respeito de um determinado país, como é o caso dos latino americanos ${ }^{17}$, maior será a importância das convenções (Andrade e Prates, 2012).

\footnotetext{
${ }^{16}$ Conforme já ressaltado, a baixa liquidez externa de uma moeda nacional resulta em dificuldades de emissão de dívidas e ativos de portfólio nela denominados, no mercado internacional.

${ }^{17}$ Como será visto adiante, estes países tendem a ser classificados como unidades especulativas ou Ponzi, utilizando a nomenclatura minskyana.
} 
Enquanto a percepção da incerteza global for baixa e as convenções estiverem favoráveis, os agentes internacionais reduzem as taxas de juros, ampliam os prazos dos empréstimos ofertados e apresentam maior demanda pelos ativos negociados nos mercados domésticos. Isso resulta em uma elevação da liquidez internacional. À medida que o país devedor conseguir pagar os compromissos externos, a conta financeira do seu balanço de pagamentos apresentará tendência de superavit. Isso, por sua vez, será refletido em valorizações graduais da sua moeda, o que aumenta a sua demanda e a dos ativos nela denominados para fins de especulação, já que os agentes se apoiam na convenção de que haverá continuidade da trajetória cambial corrente e, por isso, esperam obter ganhos de capital a partir da compra e venda posterior da moeda doméstica.

Uma eventual ampliação da incerteza, no cenário internacional, e a reversão das expectativas a respeito da solvência dos devedores pode interromper a fase de expansão da liquidez internacional, resultando em condições desfavoráveis para a oferta de financiamento. Nesse momento, apenas as economias com elevada competitividade no comércio exterior e que conseguem emitir um elevado percentual do seu passivo em moeda doméstica, no cenário internacional, conseguem honrar os compromissos externos. Esses países consistem nas unidades hedge, uma vez que o aumento da taxa de juros internacional e a desvalorização cambial não afetam a sua capacidade de pagamento dos compromissos financeiros junto a credores externos. Além disso, devido à capacidade das suas moedas nacionais desempenharem satisfatoriamente as funções clássicas em escala mundial, um aumento da percepção da incerteza global pode gerar um processo de valorização cambial a seu favor.

Essa mesma contração da liquidez internacional tem efeitos mais negativos nos países classificados como unidades especulativas e Ponzi. Por um lado, a sua incapacidade de geração de divisas estrangeiras se torna evidente (Resende e Amado, 2007). A contração do refinanciamento externo reduz a sua solvência, reforçando a tendência de fuga de capital. Por outro lado, sua moeda nacional é demandada predominantemente pelo motivo especulação, devido a sua posição inferior na hierarquia internacional, enquanto houver crescimento do superavit financeiro. Assim que a percepção de incerteza global aumenta, há recuo na demanda por sua moeda, o que leva a uma queda do seu valor em termos das moedas de maior conversibilidade.

É importante ressaltar que a elevação da taxa de juros internacional e a desvalorização da moeda doméstica aumentam o custo do passivo externo dos países especulativos e Ponzi. Nesse sentido, a fuga de capital dessas economias reduz ainda mais sua capacidade de solvência. Para conseguir honrar os compromissos financeiros junto aos agentes internacionais, possibilitar que estes convertam para moeda estrangeira o montante investido no mercado de portfólio doméstico e obter as divisas estrangeiras necessárias para fazer face aos gastos correntes, sem uso de reservas cambiais, esses países aumentam a oferta dos seus ativos, tentando vendê-los a preços cada vez mais aviltados. A redução das receitas e a queda do preço dos ativos domésticos geram, por sua vez, queda no nível de emprego e no desempenho macroeconômico desses países, evidenciando a não neutralidade da moeda. Dessa forma, na fase de contração da liquidez internacional, tende a ocorrer também um processo de desvalorização de ativos, com impactos negativos sobre o nível de emprego e renda, conforme observado por Kregel (1998), Arestis e Glickman (2002) e Dimsky (1998). Cumpre destacar que, em contexto de câmbio flutuante, os investidores estrangeiros detentores de títulos de renda fixa e ações negociados em âmbito doméstico, tendem a compartilhar as perdas decorrentes do processo deflacionário com a economia nacional, uma vez que só conseguem vendê-los a preços menores em termos de moeda.

Além disso, a não neutralidade da moeda se manifesta também em uma tendência de elevação da taxa de juros doméstica como resultado do aumento dos juros internacionais e da 
desvalorização da moeda doméstica. Ocorre, assim, um crescimento do custo de oportunidade do investimento nacional, bem como um recuo no seu retorno financeiro, diante do processo de desvalorização de ativos, ou seja, da diminuição do preço de demanda do investimento e da tendência de redução do nível de emprego e renda domésticos. Nesse sentido, Resende e Amado (2007) observam que a variação da liquidez internacional tende a afetar as variáveis macroeconômicas dos países classificados como unidades especulativas ou Ponzi, no sistema financeiro internacional, exercendo impacto sobre a sua taxa de crescimento.

Ao elevar a instabilidade da taxa de câmbio e da taxa de juros, como decorrência da volatilidade de expectativas em âmbito internacional, a abertura financeira aumenta a incerteza nas economias consideradas especulativas ou Ponzi. O impacto sobre o emprego e a renda ocorre em razão principalmente da instabilidade macroeconômica, que, por acentuar a incerteza, influencia o investimento.

Assim, verifica-se que a abertura financeira tem efeitos diferenciados entre os países, dependendo da sua postura comercial e financeira. Esta depende da sua capacidade de emissão de moeda e ativos com elevado grau de liquidez internacional e de geração de fluxos de receita em divisas estrangeiras, por meio de operações correntes e financeiras. Para um melhor entendimento da instabilidade do capitalismo manifestada nos países da América Latina, é fundamental relacionar a forma como estas economias se inserem no sistema financeiro e monetário internacional e no comércio exterior às suas estruturas produtivas e financeiras domésticas. Para isso, é preciso levar em consideração a existência de um sistema centro-periferia, em âmbito internacional, caracterizado pela diferenciação entre os países, em termos da dinâmica apresentada pelas variáveis reais e monetárias, ressaltando a interação entre elas.

\section{Aspectos Estruturais do Sistema Centro-Periferia}

\subsection{A Concepção Estruturalista}

A introdução da concepção do sistema centro-periferia, no âmbito das teorias de desenvolvimento econômico, remonta ao pensamento estruturalista da Comissão Econômica para a América Latina e Caribe (Cepal), desenvolvido entre o final da década de 1940 e o início da década de 1980. A sua principal motivação consistia em explicar, a partir do método analítico "histórico-estrutural" (Bielschowsky, 2009), as especificidades da estrutura produtiva das economias latino-americanas, que as diferenciam das economias mais desenvolvidas e têm consequências significativas em termos dos seus respectivos padrões de crescimento e desenvolvimento e das formas de inserção na economia global.

O sistema centro-periferia é considerado pelo estruturalismo consequência de um fenômeno histórico, resultante da forma como o progresso técnico impulsionado a partir da Revolução Industrial foi propagado mundialmente. Por um lado, os países pertencentes ao centro geram métodos de produção difundidos para os demais e para as suas regiões internas e maioria dos setores produtivos. Por outro lado, os países periféricos não são geradores de conhecimentos técnicos substanciais, obtendo um acesso tardio às novas técnicas desenvolvidas no centro. Ademais, estas são incorporadas em um número limitado de setores, havendo baixa difusão para o restante da estrutura produtiva periférica. Dessa forma, enquanto há uma homogeneidade setorial, em termos de adoção de técnicas produtivas, no centro, observa-se uma heterogeneidade na periferia, em que setores exportadores de elevada produtividade coexistem com setores arcaicos, cuja produção se destina ao mercado doméstico (Bielschowsky, 2009; Rodriguez, 2009).

Entre os principais trabalhos desenvolvidos pela Cepal que explicam a diferença entre as estruturas produtivas do centro e as da periferia, destacam-se Prebisch (1949; 1952), Cepal 
(1949), Furtado (1983) e Tavares (1976). Segundo eles, a divisão internacional do trabalho tem beneficiado principalmente os países centrais, que são, em sua maioria, exportadores de produtos industrializados. Devido à tendência de longo prazo de deterioração dos termos de troca, o comércio internacional tende a concentrar os frutos do progresso técnico nestes países, ampliando o diferencial entre a sua renda real e a dos países periféricos, que são predominantemente primário-exportadores.

Outra implicação importante da tendência de longo prazo de deterioração dos termos de troca diz respeito ao surgimento de desequilíbrios externos. A progressiva redução dos preços das exportações das economias periféricas em relação aos preços de importações de bens industrializados leva a uma redução das suas receitas externas, portanto a um problema de escassez de divisas. Isso, por sua vez, dificulta o acesso da sua população a bens de consumos duráveis e não duráveis, além de afetar negativamente a realização de investimentos, tendo em vista que a maior parte dos bens de capital são provenientes dos países centrais.

O problema da escassez de divisas pode ser atenuado por empréstimos externos cujos serviços são recorrentemente pagos por meio de endividamentos adicionais de mesma natureza, devido à insuficiência de receitas comerciais em moeda estrangeira. Assim, pode-se observar que as economias periféricas, segundo o pensamento estruturalista, seriam equivalentes a unidades especulativas ou mesmo Ponzi, utilizando a nomenclatura desenvolvida por Minsky (1986). Elas apenas podem dar prosseguimento ao seu processo de desenvolvimento e industrialização, enquanto houver acesso ao financiamento externo, seja para viabilizar o investimento, seja para possibilitar o pagamento dos compromissos externos. A interrupção desse acesso gera, portanto, graves problemas para esses países, que podem ser amenizados a partir do desenvolvimento de setores produtivos domésticos que passem a ofertar, no mercado interno, os bens importados.

\subsection{A Concepção Neoestruturalista}

Diante dos acontecimentos históricos observados a partir da década de 1980, e tendo em vista a metodologia histórico-estruturalista do pensamento da Cepal, verifica-se uma mudança de parte do seu foco de análise e a introdução de novos conceitos na sua abordagem sobre as especificidades da América Latina como economias periféricas, em comparação aos países centrais do sistema (Bielschowsky, 2009; Rodriguez, 2009). Passa a se questionar, utilizando conceitos e análises próximas ao referencial neo-schumpeteriano, a forma como a industrialização vinha ocorrendo na região, entendendo-se que o desenvolvimento dos setores manufatureiros, a partir do processo de substituição de importação, foi baseado em uma imitação passiva das tecnologias utilizadas nos países centrais (Fajnzylber, 2000). Nesse sentido, são enfatizadas as deficiências no exercício da criatividade e nos processos de aprendizado, considerados como pré-requisitos para o avanço tecnológico contínuo e aumento da competitividade internacional dos países periféricos.

No que se refere especificamente à inserção internacional dos países periféricos, o neoestruralismo se diferencia do estruturalismo por colocar menor ênfase na composição puramente setorial da pauta exportadora, dando maior destaque ao impacto do progresso técnico sobre a competitividade internacional das economias periféricas. Nesse sentido, critica-se também a ideia ortodoxa segundo a qual os países devem se especializar na produção de bens ou serviços que utilizem os fatores produtivos com maior disponibilidade ou abundância interna e, portanto, com menor custo em comparação ao resto do mundo. Para o neoestruralismo, a competitividade resultante de baixos salários ou baixos custos de matériaprima tem um caráter espúrio, tendendo a ser anulada pelo progresso técnico, que gera novos 
processos ou novos produtos, de forma a modificar as relações de custos inicialmente associadas à dotação de fatores produtivos (Rodriguez, 2009).

A competitividade autêntica, de maior sustentabilidade ao longo do tempo, é proveniente do progresso técnico contínuo. A agregação de conhecimento aos bens e serviços domésticos, em conjunto com o aumento do encadeamento entre os diversos setores e segmentos produtivos e com a redução da heterogeneidade setorial, favorece a inserção internacional das economias periféricas, ao aumentar as suas receitas de exportação e, consequentemente, a disponibilidade de divisas para fazer face aos gastos com importação e aos compromissos financeiros em moeda estrangeira.

Nesse sentido, a concepção neoestruturalista do sistema centro-periferia está mais associada aos diferentes graus de desenvolvimento dos sistemas nacionais de inovação ${ }^{18}$ entre os países periféricos e os centrais do que à diferença em relação à composição setorial, considerada no sentido amplo (bens primários, bens de consumo não duráveis e semi duráveis, bens de consumo duráveis, bens intermediários, bens de capital e serviços), das suas respectivas estruturas produtiva. Em relação a este aspecto, cumpre destacar que dentro de uma mesma categoria setorial (por exemplo, bens intermediários), pode haver heterogeneidade no que diz respeito à intensidade de utilização de conhecimento científico e tecnológico e à agregação de valor. Dessa forma, apesar do grau de desenvolvimento do sistema nacional de inovação ter impactos sobre a estrutura produtiva, o fato de haver uma elevada participação de setores manufaturados na estrutura produtiva não implica necessariamente em uma elevada capacidade de utilização e adaptação do conhecimento técnico disponível ou de geração de novas tecnologias. Levando em consideração que a competitividade de um país está relacionada à sua capacidade de absorção e geração de conhecimento tecnológico (Fajnzylber, 1990; Fagerberg, 1994), a mera observação da composição setorial, em grandes categorias ${ }^{19}$, de uma economia não permite obter conclusão significativa a respeito da sua inserção no comércio internacional e, portanto, da sua capacidade de geração de divisas a partir de receitas correntes.

Assim, as dificuldades de obtenção de superavits comerciais sustentáveis e o consequente estrangulamento externo das economias latino-americanas estão associados, segundo o neoestruturalismo, ao baixo grau de desenvolvimento dos seus sistemas nacionais de inovação, que não fornecem incentivos suficientes para a geração contínua de progresso técnico. Devido à baixa competitividade autêntica dessas economias, elas precisam recorrer frequentemente aos mercados internacionais para refinanciarem seus passivos externos, sendo vulneráveis a variações na taxa de juros internacional e na taxa de câmbio. Ao relacionar a concepção neoestruturalista à pós-keynesiana, é possível concluir que as deficiências na estrutura de geração ou absorção de conhecimento tecnológico dos países periféricos resultam na sua baixa competitividade autêntica e comprometem sua capacidade de geração de divisas estrangeiras, a partir de receitas comerciais, em montante suficiente para possibilitar o pagamento dos compromissos externos, o que possibilita classificá-los como unidade especulativa ou Ponzi, no âmbito do sistema financeiro internacional.

\subsection{A Vulnerabilidade Externa dos Países da América Latina}

Ainda no âmbito do pensamento neoestruturalista, alguns trabalhos publicados a partir da década de 1990 demonstram clara preocupação com a vulnerabilidade da América Latina à

\footnotetext{
${ }^{18}$ Ambiente institucional que engloba as interações entre os diversos setores produtivos, as instituições financeiras e os institutos de ensino e pesquisa e fornece os incentivos para a realização de atividades de inovação tecnológica (Rodriguez, 2009).

19 Bens primários, bens de consumo não duráveis e semiduráveis, bens de consumo duráveis, bens intermediários, bens de capital e serviços.
} 
volatilidade dos fluxos internacionais de capital, exacerbada pela integração aos mercados financeiros globais. Alguns estudos produzidos pela Cepal e por economistas neoestruturalistas, como Abeles e Valdecantos (2016), Cepal (2001), Ocampo (2001) e FfrenchDavis e Ocampo (2001), focaram as suas análises na composição do balanço de pagamento dos países latino-americanos, com ênfase nos componentes da conta financeira, e seus impactos sobre a instabilidade macroeconômica e sobre o processo de desenvolvimento dessas economias $^{20}$.

Esses trabalhos ressaltam, em primeiro lugar, o aumento do peso de fluxos de curto prazo, a partir da década de 1990, na conta financeira dos países latino-americanos, havendo destaque para os empréstimos interbancários ${ }^{21}$. Isso, por sua vez, favoreceu a ocorrência de descasamentos de prazo e de unidade de conta entre passivos e ativos dos residentes na região, o que aumenta a sua vulnerabilidade em relação a variações na taxa de câmbio e na taxa de juros internacional, advindas de reversões nas expectativas dos investidores.

Em segundo lugar, observa-se que o desempenho macroeconômico desses países está diretamente relacionado às variações tanto nos fluxos internacionais de capital, quanto nos termos de troca. Nesse sentido, ressalta-se que os impactos macroeconômicos das finanças externas têm efeitos predominantemente de curto prazo, tornando a trajetória do produto real instável (Ffrench-Davis, 2014).

Em terceiro lugar, os trabalhos neoestruturalistas (Ffrench-Davis, 2014; Ocampo, 2001; Ffrench-Davis e Ocampo, 2001) enfatizam também o impacto negativo que o aumento do influxo de capital externo gera sobre o saldo em transações correntes e sobre a estrutura produtiva dos países latino-americanos. Mais precisamente, a valorização da taxa de câmbio resultante do crescimento do influxo líquido de capital leva a um aumento das importações, desincentivando a produção e os investimentos nos setores de bens manufaturados transacionáveis. A taxa de câmbio permanece competitiva apenas para os bens primários, levando ao que a literatura denomina por "doença holandesa" ${ }^{22}$, que tende a agravar a heterogeneidade estrutural, aumentando a concentração da pauta exportadora em bens primários.

Dessa forma, há certa convergência entre os pensamentos pós-keynesiano e neoestruturalistas no que diz respeito à natureza volátil dos fluxos internacionais de capital e aos seus impactos sobre a instabilidade macroeconômica, o investimento e o desenvolvimento econômico. Isso leva às duas escolas de pensamento econômico a serem mais cautelosas e reticentes quanto à abertura financeira, posicionando-se a favor, por exemplo, de controles de capital. No entanto, o neoestrutulismo carece de um maior aprofundamento quanto à incerteza e as especificidades da moeda e do sistema financeiro capitalista e suas repercussões sobre o grau de vulnerabilidade externa apresentada pelas economias periféricas.

\footnotetext{
${ }^{20}$ A preocupação em relação ao aumento da instabilidade econômica proveniente dos fluxos financeiros internacionais está presente também nos trabalhos neoestruturalistas que tratam da importância do fortalecimento de mecanismos de cooperação regional, como, por exemplo, Ocampo (2006). Neste caso, defende-se o fortalecimento de instituições financeiras regionais, o aumento do diálogo macroeconômico e a coordenação de políticas entre vizinhos como forma de prevenir crises externas, evitar o contágio destas, respaldar a regulação e a supervisão prudenciais dos sistemas financeiros domésticos, entre outros objetivos. Para mais detalhes, ver Ocampo (2006).

${ }^{21}$ Nesse sentido, Ffrench-Davis e Ocampo (2001) observam que, enquanto na década de 1970, havia um predomínio dos fluxos de capital de longo prazo destinados a financiar o setor público, a partir da década de 1990, o financiamento externo tem caráter de curto prazo, sendo mais voltado para o setor privado.

${ }^{22}$ Bresser-Pereira e Gala (2010) aprofundam melhor esse tema.
} 
Não se verifica, nos trabalhos neoestruturalistas, uma vinculação explícita entre a incerteza, o processo de escolha de ativos por parte dos agentes, nos moldes da teoria da preferência pela liquidez pós-keynesiana, e a volatilidade dos fluxos de capital entre as fronteiras dos países periféricos. Em outras palavras, não há uma associação clara entre a preferência por ativos de maior liquidez no ambiente internacional, como, por exemplo, aqueles denominados em moeda de maior conversibilidade e/ou de curto prazo, a variação da percepção sobre a incerteza por parte dos investidores internacionais e a volatilidade macroeconômica apresentada pela periferia. Nesse aspecto, há espaço então para uma conciliação entre as teorias estruturalistas e neoestruturalistas e a pós-keynesiana, levando em consideração a preocupação de ambas em relação ao aumento da vulnerabilidade externa, no contexto de globalização financeira.

\section{As Assimetrias Monetárias e Financeiras}

Uma melhor compreensão da polarização entre centro e periferia, no sistema financeiro internacional e da sua consequência sobre a instabilidade macroeconômica dos países periféricos requer a retomada dos conceitos subjacentes à teoria da preferência pela liquidez e à hipótese de fragilidade financeira para economias abertas, associando-os às concepções estruturalista e neoestruturalista. Assim, é importante ressaltar, em primeiro lugar, a existência de uma hierarquia entre as moedas nacionais em âmbito internacional, relacionada à sua capacidade de desempenhar as funções clássicas no cenário externo, o que é consequência de fatores geopolíticos e geoeconômicos (De Conti, Prates e Plihon, 2015; 2014).

As moedas emitidas pelas economias periféricas ocupam posição inferior nessa hierarquia, refletindo sua baixa liquidez em comparação com as dos países centrais. $O$ fato das moedas desses países não conseguirem desempenhar satisfatoriamente as suas funções clássicas no cenário internacional resultam em uma reduzida capacidade de emissão de passivos externos nelas denominados (Kaltenbrunner, 2015; Carneiro, 2008; Prates, 2002). Uma vez que suas moedas não são satisfatoriamente utilizadas como unidade de conta dos contratos firmados com o exterior e nem como meio para a sua liquidação, a periferia se depara com maior incerteza no que diz respeito à obtenção de fluxos de caixa compatíveis com as suas obrigações. Para honrar seus compromissos denominados em moeda estrangeira, elas recorrem a três principais alternativas: (i) geração de receitas correntes externas, comprometida pela sua baixa competitividade autêntica, relacionada ao reduzido grau de desenvolvimento dos seus sistemas nacionais de inovação; (ii) venda de ativos ou da própria moeda nacional em troca de divisas, dificultada pelo pequeno grau de liquidez da sua moeda, com posição inferior na hierarquia internacional; e (iii) utilização das reservas cambiais, cuja diminuição não é considerada desejável por afetar negativamente a confiança dos agentes em relação a solvência doméstica, baseada em convenções. Dessa forma, tende a haver obstáculos para a geração de divisas suficientes para o pagamento dos compromissos externos em vencimento.

Ao facilitar e reduzir os custos operacionais das transações internacionais, a globalização financeira tem o potencial de ampliar os passivos dos países periféricos denominados em moeda estrangeira, tornando-os vulneráveis a oscilações nas taxas de câmbio e de juros internacional, que refletem geralmente a preferência pela liquidez dos investidores externos. Ademais as diversas moedas nacionais passam a ser transacionadas como ativos financeiros, para fins de especulação. Assim, de forma semelhante à demanda por ativos financeiros, a demanda pela moeda doméstica passa a ser influenciada em grande medida pela preferência pela liquidez dos agentes internacionais, sendo suscetível ao animal spirits e a mudanças nas convenções. Esses dois fatores, por sua vez, tornam voláteis a taxa de câmbio, a taxa de juros e os preços dos ativos, aumentando a instabilidade da trajetória macroeconômica das economias periféricas. 
Como a moeda dos países periféricos não desempenha satisfatoriamente, em âmbito internacional, as funções clássicas, não há limite para a desvalorização cambial, deflagrada por mudanças nas expectativas dos agentes internacionais (De Conti, Prates e Plihon, 2014). A expectativa de perda de valor do ativo doméstico, em termos da moeda internacional, leva por si só a um processo brusco de desvalorização cambial, que poderia ser interrompido caso a moeda doméstica fosse demandada internacionalmente pelos motivos transação e precaução, ou mesmo pelo motivo finanças, além do motivo especulação. Porém, este não é o caso.

Dessa forma, a posição das moedas dos países periféricos na hierarquia internacional amplifica as oscilações nas trajetórias de suas taxas de câmbio e, portanto, de juros, tornando o desempenho macroeconômico mais instável. Além disso, a elevada incerteza e o alto riscopaís associados a essas economias tornam suas taxas de juros potencialmente superiores às das economias centrais (De Conti, Prates e Plihon, 2014). Ora, tanto a maior volatilidade das taxas de câmbio e de juros quanto os maiores patamares desta última impactam negativamente o investimento nas economias periféricas. Assim, a abertura financeira amplia o diferencial entre as suas trajetórias de desenvolvimento e as dos países centrais.

Além da assimetria monetária, relacionada à hierarquia de divisas no sistema internacional, destaca-se também a existência de assimetria financeira. Esta diz respeito tanto aos determinantes do fluxo de capitais que se direcionam para as economias periféricas, quanto ao seu volume e composição (Prates, 2002; Andrade e Prates, 2012).

Em primeiro lugar, as decisões a respeito do montante e da direção dos fluxos financeiros são tomadas, principalmente, nos países centrais, sendo influenciadas pelo momento do ciclo econômico em que estes países estão, pelo estado da preferência pela liquidez dos seus agentes e por decisões de caráter político. Dessa forma, os fluxos de capital em direção à periferia do sistema financeiro internacional são determinados por variáveis exógenas a eles, sendo afetados em grande parte pela condução da política econômica pelos outros países e pelo estado de confiança dos seus agentes.

Em segundo lugar, o sistema financeiro doméstico das economias periféricas latinoamericanas tende a ser menos desenvolvido que o das economias centrais, conforme destacado por alguns trabalhos neoestruturalistas, como Vera e Pérez-Caldentey (2015) e Vera e Titelman (2013), e alguns pós-keynesianos, como Hermann (2014) e Studart (2001). Os mercados de capital da periferia costumam ter tamanho reduzido e pouca profundidade, quando comparados ao centro. Assim, o financiamento ao investimento é, em grande medida, realizado por meio de créditos bancários, que, ainda assim, são limitados, não satisfazendo plenamente a demanda existente. Nesse sentido, ele é complementado por crédito privado externo e por emissões de títulos e de ações junto a agentes estrangeiros. Além disso, o próprio processo de desenvolvimento desses países, que utilizam insumos manufaturados, bens de capital e tecnologia importados dos países centrais resulta na necessidade de divisas estrangeiras que, uma vez não obtidas por meio de receitas de exportação, são satisfeitas por meio de financiamento externo. Assim, verifica-se uma elevada participação de recursos advindos do exterior nos passivos totais ${ }^{23}$.

Apesar da importância dos fluxos de capitais globais para os países periféricos, a parcela destinada a estes países em relação ao total do financiamento concedido é pouco significativa, o que caracteriza uma inserção marginal nos fluxos globais (Prates, 2002; Andrade e Prates, 2012). Uma vez que a participação dos ativos periféricos no portfólio dos agentes que atuam em âmbito global tende a ser residual, sua venda não possui impactos significativos sobre a rentabilidade total da carteira. No entanto, ela pode gerar pressões de desvalorização

23 Essa participação é ainda maior se for considerado os empréstimos intercompanhia e o crédito ofertado por bancos sediados no exterior, mas com filiais ou subsidiárias nessas economias. 
cambial na economia periférica, majorando o valor do passivo externo em relação aos fluxos de receita. Além disso, pode reduzir a disponibilidade de divisas para fazer face às obrigações junto com o exterior, o que, em conjunto com a baixa capacidade de obtenção de receitas comerciais sustentáveis ao longo do tempo, torna necessário que o país recorra a novos financiamentos ou faça uso de parcela do estoque de reservas cambiais ${ }^{24}$.

É importante destacar que há um autorreforço entre as assimetrias monetárias e as financeiras (Andrade e Prates, 2012). Tendo em vista que os fluxos financeiros em direção às economias periféricas são determinados por uma dinâmica exógena a eles, nos momentos em que há mudanças nas fases de ciclo econômico nos países mais desenvolvidos, alterações na condução das suas políticas ou aumento na preferência pela liquidez internacional, há uma redução da demanda pelos ativos e moedas periféricos, que não desempenham satisfatoriamente a função de reserva de valor e não são utilizados para a liquidação dos compromissos contratuais em vencimento. Assim, há pressão para desvalorização cambial, que eleva a razão entre as obrigações externas e o fluxo de receitas.

Ademais, o autorreforço ocorre devido à inserção marginal dos países periféricos nos fluxos financeiros globais, que aumenta a volatilidade das suas respectivas taxas de câmbio em termos da divisa-chave e de outras moedas posicionadas próximas ao topo da hierarquia internacional. Como as vendas dos ativos periféricos possuem impacto pouco significativo sobre a rentabilidade dos portfólios globais, sendo sua participação residual, o investidor internacional se desfaz deles com maior frequência, o que agrava a volatilidade cambial e compromete ainda mais o desempenho da função de reserva de valor.

Em suma, o baixo desenvolvimento dos mercados financeiros dos países periféricos, a oferta limitada de créditos bancários em âmbito doméstico, a reduzida liquidez das suas moedas e o baixo desenvolvimento de setores intensivos em tecnologia, inclusive o de bens de capitais, propiciam que essas economias assumam compromissos denominados em moeda estrangeira, tornando-os vulneráveis a variações cambiais e de juros. Devido à existência de assimetrias monetárias e financeiras internacionais, o impacto do aumento da preferência pela liquidez em âmbito global tende a ser mais grave nos países periféricos do que nos países centrais, o que reforça a tendência a predominância de ciclos econômicos de maior amplitude e mais curtos na periferia.

A abertura financeira resulta, então, em uma dinâmica perversa para os países periféricos, pois, além de propiciar o aumento de passivos denominados em moeda estrangeira, eleva a volatilidade das suas taxas de câmbio e de juros, devido às assimetrias monetárias e financeiras. Assim, elas se tornam mais vulneráveis a variações nas taxas de juros e de câmbio e estas se tornam mais frequentes e mais bruscas, devido ao aumento do volume bruto de recursos utilizados para fins de especulação. Em conjunto, essas variações afetam o montante do passivo externo em relação ao fluxo de receitas, que é comprometido pela baixa competitividade autêntica desses países, resultante do insuficiente grau de desenvolvimento dos seus sistemas nacionais de inovação. Assim, as assimetrias monetárias e financeiras internacionais e as deficiências na estrutura produtiva e tecnológica das economias periféricas aumentam sua vulnerabilidade externa, compreendida a partir da razão entre compromissos em moeda estrangeira e fluxos de receitas internacionais, possibilitando a sua classificação em unidades especulativas e Ponzi.

\footnotetext{
${ }^{24}$ Segundo Santiago (2016), houve acúmulo substancial de estoque de reservas por parte da América Latina, em termos agregados, ao longo da década de 2000, o que permitiu que os países acomodassem melhor as pressões advindas de variações na preferência pela liquidez dos investidores internacionais. Esse resultado é influenciado pelas estratégias adotadas pelo Brasil e pelo México, que possuem um elevado peso na região.
} 


\section{Uma Caracterização Integrada dos Países Periféricos Latino-Americanos}

Para permitir uma melhor compreensão da inserção das economias latino-americanas no cenário internacional, no contexto da globalização financeira, é preciso levar em consideração as especificidades tanto das suas estruturas produtivas e tecnológicas, discutidas pelos trabalhos estruturalistas e neoestruturalistas, quanto das suas moedas e estruturas financeiras, segundo a concepção teórica pós-keynesiana. Nesse sentido, as principais características desses países que os diferenciam dos países centrais são: (i) baixa competitividade dos seus bens e serviços, decorrente do baixo grau de desenvolvimento relativo dos seus sistemas nacionais de inovação; (ii) concentração da pauta exportadora em bens primários e da pauta de importação em bens de capital, insumos processados e bens de consumo duráveis, que tendem a resultar em estrangulamento externo e aumentar a dependência de financiamento externo para a realização de investimentos e, portanto, para o processo de crescimento econômico; (iii) reduzida liquidez das moedas nacionais e dos ativos financeiros nelas denominados, que torna suas respectivas demandas pelos agentes internacionais predominantemente especulativas e se reflete em obstáculos tanto para a emissão de ativos denominamos em moeda nacional, em âmbito externo, quanto para a conversão de ativos e moedas domésticos em divisas em posição superior na hierarquia internacional, que possuem maior liquidez e conferem maior flexibilidade e segurança para 0 seu detentor; (iv) inserção marginal nos fluxos internacionais de capital, que resulta em maior volatilidade das taxas de câmbio e de juros e reforça a assimetria monetária; e (v) baixo desenvolvimento do mercado financeiro, que acentuam sua dependência em relação ao financiamento externo e tornam essas economias sujeitas a variáveis exógenas, determinantes do fluxo financeiro, relacionadas a questões políticas e econômicas dos países centrais e a preferência pela liquidez dos seus residentes.

Por um lado, as particularidades da moeda e do sistema financeiro das economias latino-americanas resultam em uma maior propensão à contração de obrigações denominadas em moeda estrangeira. Por outro lado, o baixo grau de desenvolvimento dos seus sistemas nacionais de inovação e a concentração da pauta exportadora em bens primários e da pauta de importação em bens de capital, insumos processados e bens de consumo duráveis tendem a reduzir sua competitividade externa e a aumentar o valor de despesas de importação em moeda estrangeira. Dessa forma, tende a haver uma elevada razão entre os compromissos junto ao exterior e os fluxos de caixa compatíveis, em termos de unidade de conta, com as obrigações devidas. Assim, o conjunto dessas características permite classificar os países da América Latina em unidades especulativas e Ponzi, estando vulneráveis a variações da preferência pela liquidez internacional, que se refletem em variações nas taxas de câmbio e de juros e, por isso, afetam o valor do passivo externo e as condições de seu refinanciamento.

O próprio processo de crescimento econômico dos países latino-americanos, apoiado em capital externo, tende a fragilizar externamente as suas economias. Para viabilizar a realização de investimentos, a partir da importação de bens de capital e de tecnologia estrangeira, esses países recorrem frequentemente a financiamentos externos, contraindo compromissos em moeda estrangeira, devido à reduzida liquidez de suas moedas no sistema internacional. No entanto, a baixa competitividade dessas economias dificulta a canalização de recursos externos, por meio de receitas de exportação, para a consolidação do investimento, de forma a reduzir ou eliminar os descasamentos entre ativos e passivos em termos de unidades de conta e prazos. Em outras palavras, há obstáculos para o encerramento do ciclo financiamento-investimento-poupança-funding, devido às especificidades das moedas dos países periféricas e das suas respectivas estruturas produtivas, tecnológicas e financeiras.

Uma vez que não conseguem obter superavits comerciais sustentáveis, em montante suficiente para o pagamento dos compromissos externos, as economias periféricas recorrem 
frequentemente aos mercados financeiros internacionais para fechar suas posições em aberto. Ora, o refinanciamento do passivo externo torna essas economias vulneráveis a variações da taxa de câmbio e dos juros internacionais, resultantes de oscilações na preferência pela liquidez.

Por exercer impacto na taxa de juros doméstica, nas avaliações sobre risco-país e na expectativas de desvalorização cambial, a volatilidade da preferência pela liquidez internacional exerce impacto na trajetória das variáveis reais. Ademais, a instabilidade macroeconômica gerada pelas oscilações nos fluxos de capital tende a reduzir a própria confiança dos agentes em suas expectativas, contraindo, assim, os investimentos e o crescimento econômico das economias periféricas, com impacto significativo sobre o nível de emprego. Assim as especificidades das economias periféricas e a natureza da sua inserção no cenário internacional aumentam a sua instabilidade macroeconômica, no contexto de globalização financeira, em decorrência da existência de restrição externa ao seu processo de crescimento.

\section{Referências Bibliográficas}

Abeles, M. e Valdecantos, S. (2016) "Vulnerabilidad Externa en America Latina y el Caribe - Um Análisis Estructural". Serie Estudios y Perspectivas, n.49, Cepal, Buenos Aires.

Akyüz, Y. (2015) "Internationalization of Finance and Changing Vulnerabilities in Emerging and Developing Economies". South Centre Research Paper, n. 60.

Amado, A.M. (2004) "Preferência pela Liquidez: o Novo Contexto Financeiro Internacional Inviabiliza a Teoria?" Revista de Economia Política, 24(4), p. 500-13.

Andrade, R.P. e Prates, D.M. (2012) "Dinâmica da Taxa de Câmbio em uma Economia Monetária Periférica: uma Abordagem Keynesiana". Nova Economia, 22(2), p. 235-57.

Arestis, P. e Glickman, M. (2002) "Financial Crisis in Southeast Asia: Dispelling Illusion The Minskyan Way". Cambridge Journal of Economics, 26(2), p. 237-60.

Belluzzo, L.G. e Carneiro, R. (2004) "O mito da conversibilidade". Revista de Economia Política, 24(2), p.218-22.

Biancareli, A. (2015) O Setor Externo da Economia Brasileira, Depois da Bonança e da Tempestade. Artigo disponível em http://brasildebate.com.br/o-setor-externo-daeconomia-brasileira-depois-da-bonanca-e-da-tempestade/.

Bielschowsky, R. (2009) "Sessenta Años de la CEPAL: Estructuralismo y Neoestructuralismo". Revista de la Cepal, n. 97, p.173-94.

Bresser-Pereira, L.C. e Gala, P. (2010) "Macroeconomia Estruturalista do Desenvolvimento". Revista de Economia Política, 30(4), p. 663-86.

Carneiro, R. (2008) "Globalização e Inconversibilidade Monetária". Revista de Economia Política, 28(4), p. 539-56.

Carvalho, F.C. (1992) Mr Keynes and The Post Keynesians. Principles of Macroeconomics For A Monetary Production Economy. Ed. Edward Elgar.

Cepal (1949 [2000]) “Estudo Econômico da América Latina, 1949”. In Bielschowsky, R. (org.) Cinquenta Anos de Pensamento na CEPAL. Rio de Janeiro: Record.

Cepal (2001) Crescer com Estabilidade - O Financiamento do Desenvolvimento no Novo Contexto Internacional. Editora Campus. 
Chesnais, F. (2005) "O Capital Portador de Juros: Acumulação, Internacionalização, Efeitos Econômicos e Políticos". In Chesnais, F. A Finança Mundializada, Ed. Boitempo.

Chick, V. (1983) Macroeconomics After Keynes. Cambridge: MIT Press.

Cintra, M. (2015) “O Financiamento das Contas Externas Brasileiras: 1995 - 2000". In Squeff, G.C. (org.) Dinâmica Macrossetorial Brasileira, Ipea, Brasília.

De Conti, B. M., Prates, D. M. e Plihon, D. (2014) "Hierarquia Monetária e Suas Implicações para as Taxas de Câmbio e de Juros e a Política Econômica dos Países Periféricos". Economia e Sociedade, 23(2), p. 341-72.

De Conti, B, Prates, D. e Plihon, D. (2015) "O Sistema Monetário Internacional e seu Caráter Hierarquizado". In: M. Cintra e A. Martins (orgs.) As Transformações do Sistema Monetário Internacional, Brasília: Ipea.

De Paula, L.F. e Alves JR. A.J.A. (1999) "Fragilidade Financeira Externa e os Limites da Política Cambial no Real". Revista de Economia Política, 19(1), p. 72-93.

Dequech, D. (2000) "Asset Choice, Liquidity Preference, and Rationality, under Uncertainty". Journal of Economic Issues, 34(1), p.159-76.

Dow, S.C. (1985) Macroeconomic Thought: A Methodological Approach. Blackwell, Oxford.

Dow, S.C. (1999) "International Liquidity Preference and Endogenous Credit Creation". In J. Deprez e J. Harvey (orgs.) Foundations of International Economics: Post Keynesian Perspectives, Routledge.

Dymski, G. (1998) “'Economia de bolha' e Crise Financeira no Leste Asiático e na Califórnia: uma Perspectiva Espacializada de Minsky". Economia e Sociedade, vol. 11, p. 73-136.

Fagerberg, J. (1994) "Technology and international differences in growth rates". Journal of Economic Literature, Vol XXXII, September, p. 1147-75.

Fajnzylber, F. (1990 [2000]) "Industrialização da América Latina: da 'Caixa Preta' ao 'Conjunto Vazio'". In Bielschowsky, R. (org.) Cinquenta Anos de Pensamento na CEPAL. Rio de Janeiro: Record.

Ffrench-Davis, R. (2014) "Neoestructuralismo y Macroeconomia para el Desarrollo". Serie de Documentos de Trabajo, 391, Facultad Economía y Negocios, Departamento de Economía, Universidad de Chile. Santiago.

Ffrench-Davis, R. e Ocampo, J.A. (2001) "The Globalization of Financial Volatility: Challenges for Emerging Economies". In: R. Ffrench-Davis (ed.). Financial Crises in "Successful" Emerging Economies. Cepal, Brooking Institution Press.

Furtado, C. (1983) Teoria e Política do Desenvolvimento Econômico. São Paulo: Abril Cultural.

Guttmann, R. (2015) "Chronic Macro-Economic and Financial Imbalances in the World Economy: a Meta-Economic View". Revista de Economia Política, 35(2), p. 203-26.

Harvey, J. T. (1999) "Exchange Rates: Volatility and Misalignment in the Post-Bretton Woods Era". In J. Deprez e J. Harvey (orgs.) Foundations of International Economics: Post Keynesian Perspectives, Routledge.

Hermann, J. (2014) "Financial Constraints on Economic Development: Theory and Policy for Developing Countries". Cepal Review, n.114, p.67-82.

IMF (2015a) "Adjusting to Lower Commodity Prices". World Economic Outlook, Washington: IMF. 
IMF (2015b) "Vulnerabilities, Legacies, and Policy Challenges: Risks Rotating to Emerging Markets". Global Financial Stability Report, Washington: IMF.

Kaltenbrunner, A. (2015) "A Post Keynesian Framework of Exchange Rate Determination: a Minskyan Approach". Journal of Post Keynesian Economics, 38(3), p.426-48.

Keynes, J. M. (1936 [1982]) A Teoria Geral do Emprego, do Juro e da Moeda, São Paulo: Atlas.

Keynes, J. M. (1937) "The General Theory of Employment", The Quarterly Journal of Economics, p. 209-23.

Kregel, J.A. (1998) "Yes, 'It' Did Happen Again - A Minsky Crisis Happened in Asia". Working Paper, n.234. Presented at the Eighth Annual Hyman P. Minsky Conference on Financial Structure, April 23-24.

Minsky, H. P. (1986) Stabilizing an Unstable Economy, Yale University Press.

Minsky, H. P. (1992) "The Capital Development of the Economy and The Structure of Financial Institutions". Working Paper, n.72, The Jerome Levy Economics Institute of Bard College, January.

Ocampo, J.A. (2001) "International Asymmetries and the Design of the International Financial System". Serie Temas de Coyuntura, n. 15. Santiago: Cepal.

Ocampo, J. A. (2006) “La Cooperación Financiera Regional: Experiencia y Desafíos". In Ocampo, J.A. (org.) Cooperación Financiera Regional. Santiago: Cepal.

Plihon, D. (1995) “A Ascensão das Finanças Especulativas”, Economia e Sociedade, 5, p.61-78.

Prates, D. M. (2002) Crise Financeira nos Países "Emergentes": uma Interpretação Heterodoxa. Tese de Doutoramento, Universidade Estadual de Campinas, Instituto de Economia.

Prebisch, R. (1949 [2000]) “O Desenvolvimento Econômico da América Latina e Alguns de Seus Problemas Principais", In R. Bielschowsky (org.) Cinquenta Anos de Pensamento na CEPAL. Rio de Janeiro: Record.

Prebisch, R. (1952 [2000]) "Problemas Teóricos e Práticos do Crescimento Econômico". In Bielschowsky, R. (org.) Cinquenta Anos de Pensamento na CEPAL. Rio de Janeiro: Record.

Resende, M.F.C. (2007) "O Circuito Finance-Investimento-Poupança em Economias Abertas". Revista de Economia Política, 28(1), p.136-54.

Resende, M.F.C. e Amado, A.M. (2007) "Liquidez Internacional e Ciclo Reflexo: Algumas Observações para a América Latina”. Revista de Economia Política, 27(1), p.41-59.

Rodriguez, O. (2009) O Estruturalismo Latino-Americano. Rio de Janeiro: Civilização Brasileira.

Santiago, S.Q. (2016) A Inserção da América Latina no Sistema Centro-Periferia, no Contexto de Finanças Globalizadas: Observações para México, Brasil e Argentina. Tese de Doutorado, Universidade de Brasília, Departamento de Economia.

Studart, R. (2001) "Integrating Uneven Partners: the Destabilizing Effects of Financial Liberalization and Internationalization of Latin American Economies". In Encontro Nacional da Anpec.

Torres Filho, E. T. (2014) "A Crise do Sistema Globalizado Contemporâneo". Revista de Economia Política, 34(3), p. 433-50. 